\title{
Effect of Incorporation of Potato on the Quality of Chicken Cutlets
}

\author{
Pant Chetana*, Kumar Yogesh, Anita, Bharti SK, Tanwar VK. \\ Dept.Of livestock products Technology, G.B.P.U.Agri\&Tech., Pantnagar, US Nagar, Uttarakhand, India. PIN- \\ 263145.
}

\begin{abstract}
A study was carried out to assess the effect of addition of different levels of potato (25\% and 50\%) and compared with control $(C)$ on the basis of physicochemical, proximate and sensory attributes of chicken cutlets. Results for physico-chemical analysis indicated that $\mathrm{pH}$ values of both treatments were higher than $C$ and differences were highly significant $(P<0.05)$. Cooking losses and Shrinkage values of $T_{25}$ and $T_{50}$ were significantly $(P<0.05)$ lower than that of $C$. Highly significant $(P<0.01)$ differences were observed in WHC values of treatments and $C$. Moisture retention of $T_{25}$ and $T_{50}$ were highly significant $(P<0.01)$ than $C$. Fat retention was significantly $(P<0.05)$ higher for both treatments than $C$ however protein content of $T_{25}, T_{50}$ and $C$ did not differ significantly. Moisture content of $T_{25}$ and $T_{50}$ were significantly $(P<0.05)$ higher than $C$. However, no significant differences were observed in ash content of all samples. Sensory evaluation revealed that highly significant $(P<0.01)$ scores for colour \& appearance, juiciness and overall acceptability were observed for $T_{25}$. However, no significant differences were observed for texture and flavour values. It can be concluded that potato incorporation at $25 \%$ level improves quality and also decreases cost of production of chicken cutlets.
\end{abstract}

Keywords: chicken cutlets, potato, physicochemical analysis, proximate, sensory attributes

\section{Introduction}

With rapid increase in poultry production in the country, disposal of spent birds meat becomes a challenge. About $30 \%$ of the poultry slaughtered in India are aged stocks after passing their productive life resulting in meat which is tough, less juicy with poor functional properties. This coarse textured meat needs to be subjected to special processing and cooking methods to improve tenderness (Hedrick, Aberle, Judge and Merkel, 1994; Lawrie, 1985). Meat processors can benefit from the development of efficient and economical technology for processing under-valued tough meat into value added products that are palatable and reasonable in cost. The preparation of value-added meat products enables incorporation of various binders/extenders. These processes not only bring down the cost of production but also improve palatability and yield of products. Various reports on addition of non-meat extenders and binders such as egg albumen and refined wheat flour (Padda et al, 1987), soy protein isolate (Singh and Verma, 2000), porridge flour (Pathak, 2009), milk co precipitate (Patil and Sanyal, 2001). In countries with low purchasing power like India production cost can be reduced high amounts of cheap extenders/fillers (e.g. flours, starches, potato, bread crumbs) to meat products. Cheap fillers like potato (Solanum tuberosum) can reduce cost of the product by 10-30\%. Majority of the consumers prefer slight to medium extended meat products compared to full-meat products. Fillers like starches, flours and potato increases the juiciness of the product due to their high water absorption capacity particularly at the temperature between $50^{\circ} \mathrm{C}-70^{\circ} \mathrm{C}(\mathrm{FAO})$. Keeping these points in view, the present study was undertaken to evaluate the effects of incorporation of potato at $25 \%$ and $50 \%$ levels on physic-chemical, nutritive and organoleptic qualities of chicken cutlets and their storage stability.

Further enrobing of meat products provides advantages such as preserving the nutritive value, preventing moisture and weight loss, improving tenderness and juiciness. These improvements are brought about by coating ingredients which act as sealants and also prevent high oil uptake during frying of product (Cunningham, 1989). Breading on the fried product enhances texture, flavour and appearance of the product (Rao\& Delaney, 1995).

\section{Materials And Methods}

Spent and culled broiler breeders were slaughtered hygienically in the semi-automatic poultry processing plant in the Department of Livestock Products Technology, GBPUA\&T, Pantnagar. Dressed carcasses were chilled for 4-5 hrs. and deboned manually; deboned meat was packed in polythene bags and stored in freezer till further use .Partially thawed meat was minced by passing first through $6 \mathrm{~mm}$. and then $4 \mathrm{~mm}$. plate in an electric meat mincer. In experimental trials boiled mashed potato was incorporated at $0 \%, 25 \%$ and $50 \%$ levels proportionately. Other ingredients were salt (1.7\%), dry spice mix $(2.5 \%)$ and green curry stuff (onion, garlic and ginger paste; 5:3:1). 
Meat mince was divided into three parts. No potato was added to CONTROL, 25\% was added to second part $\left(\mathrm{T}_{25}\right)$ and $50 \%$ to the third part $\left(\mathrm{T}_{50}\right)$. Meat batter was prepared by hand mixing of all the ingredients in the above mentioned proportion. The batter was moulded into the shape of cutlets. The moulded cutlets were coated with white refined flour paste and enrobed with bread crumbs. Cutlets were deep fried to golden brown in sunflower refined oil till an internal temperature of $80^{\circ} \mathrm{C}$ was reached and turned repeatedly to avoid charring.

Table 1: Composition for formulation of chicken cutlets using boiled mashed potatoes as binder

\begin{tabular}{|c|c|c|c|}
\hline INGREDIENTS(gm.) & CONTROL & $\mathrm{T}_{25}$ & $\mathrm{~T}_{50}$ \\
\hline CHICKEN MEAT & 500 & 375 & 250 \\
\hline POTATO & - & 125 & 250 \\
\hline SALT (1.7\%) & 8.5 & 8.5 & \\
\hline DRY SPICES MIX (2.5\%) & & & \\
\hline GREEN CURRY STUFF (5\%) & & & 13.88 \\
\hline ONION PASTE & 13.88 & 13.88 & 8.33 \\
\hline GARLIC PASTE & 8.33 & 8.33 & 2.77 \\
\hline GINGER PASTE & 2.77 & 2.77 & COATING \\
\hline $\begin{array}{c}\text { WHITE REFINED FLOUR } \\
\text { PASTE }\end{array}$ & COATING & COATING & ENROBBING \\
\hline BREAD CRUMBS & ENROBBING & ENROBBING & \\
\hline
\end{tabular}

The $\mathrm{pH}$ of the sample (raw batter) was recorded, immediately after preparing batter, by homogenizing $5 \mathrm{gm}$ of batter in $45 \mathrm{ml}$. of distilled water, using digital pH meter (Trout et al. 1992). Weight of raw and cooked cutlets was recorded to calculate cooking losses (\%). Length, breadth and thickness (in $\mathrm{cm}$.) of raw and cooked cutlets were recorded to determine shrinkage (\%) by formula given by El-Magoli, Laroia and Hansen (1996).

Shrinkage $(\%)=\underline{(\text { raw thickness }- \text { cooked thickness })+(\text { raw diameter-cooked diameter })}$ X 100

\section{(Raw thickness + raw diameter)}

Water holding capacity (\%) was calculated by mixing $20 \mathrm{gm}$ of meat batter with $30 \mathrm{ml}$. Of $0.6 \mathrm{M} \mathrm{NaOH}$ in polycarbonate centrifuge tube and was stirred for 1 minute.The tube was then kept at refrigerated temperature $\left(4 \pm 1^{\circ} \mathrm{C}\right)$ for $15 \mathrm{~min}$, stirred again and centrifuged at $500 \mathrm{rpm}$ for $10 \mathrm{~min}$. The supernatant was measured and amount of water retained by samples was expressed as WHC in percentage.

The moisture content was determined by hot air oven drying, fatby Soxhlet extraction with petroleum ether, protein by automatic Kjeldahl method and total ash contents of the chicken cutlets were estimated by muffle furnace as per AOAC.

Moisture (\%) of the cooked and raw sample was used to calculate moisture retention (\%) which represent the amount of moisture retained in the cooked per $100 \mathrm{gm}$ of the raw sample. The value was calculated according to the following equation as described by El-Magoli et al. (1996).

Moisture retention $(\%)=(\%$ cooking yield $\mathrm{X} \%$ moisture in cooked product $) / 100$

A semi-trained panel comprising of faculty and PG students of the college were used for sensory evaluation of the product viz., colour and appearance, flavour, texture, juiciness and overall acceptability using 8 point hedonic scale (Keeton ,1983) where 8- extremely good and 1-extremely poor. Pooled data from three trials were statistically analysed (Snedecor \& Cochran, 1989) by analysis of variance.

\section{Physico-chemical characteristics:}

\section{Results And Discussion}

The results of various physico-chemical characteristics influenced by different levels of potato were presented in Table 2. Cooking loss is the important parameter to predict the behaviour of various additives like binders and non-meat ingredients during cooking. In the present investigation cooking losses of $\mathrm{T}_{25}$ and $\mathrm{T}_{50}$ were significantly $(\mathrm{P}>0.05)$ lower than CONTROL. CONTROL cutlets had the highest cooking losses, while the $\mathrm{T}_{25}$ and $\mathrm{T}_{50}$ differed non-significantly. Thus; incorporation of potato increased the moisture retention in the products during cooking (Keeton, 1994), as a result lowering the cooking losses, thereby increasing the cooking yield. Similar, results were recorded by Sharma et al. (1998) and Pathak et al. (2009).

The influence of addition of potato on $\mathrm{pH}$ values of chicken cutlets was clearly observed in this study. As the level of potato was increased the corresponding values for $\mathrm{pH}$ also increased gradually (Yilmaz and Daglioglu , 2003). Studies with respect to water holding capacity (WHC) of raw cutlets have shown that incorporation of potato significantly increased water holding capacity from 46.66 to 56.22 and the differences were highly significant $(\mathrm{P}<0.01)$. This might be due to higher moisture absorbance capacity of boiled potato in meat emulsion. Boiled potato can absorb large quantity of water without increase product viscosity. Shrinkage values of $\mathrm{T}_{25}$ and $\mathrm{T}_{50}$ were significantly $(\mathrm{P}<0.05)$ lower than that of CONTROL. Moisture retention of potato added cutlets showed highly significant $(\mathrm{P}<0.01)$ values than that of CONTROL. This is due to high moisture 
absorption capacity of potato added cutlets. Fat retention capacity was significantly $(\mathrm{P}<0.05)$ higher for treatment compared to CONTROL.

Table 2: Effect of incorporation of boiled potato on Physico-chemical characteristics of chicken cutlets

\begin{tabular}{|c|c|c|c|}
\hline PARAMETERS & CONTROL & $\mathbf{T}_{25}$ & $\mathbf{T}_{\mathbf{5 0}}$ \\
\hline COOKING LOSS & $14.5600 \pm 0.4313^{\mathrm{b}}$ & $12.7666 \pm 0.1666^{\mathrm{a}}$ & $13.2400 \pm 0.1258^{\mathrm{a}}$ \\
\hline $\mathrm{pH}$ & $6.1300 \pm 0.0116^{\mathrm{b}}$ & $6.0500 \pm 0.02085^{\mathrm{a}}$ & $6.2166 \pm 0.0202^{\mathrm{c}}$ \\
\hline $\begin{array}{c}\text { WATER HOLDING } \\
\text { CAPACITY }\end{array}$ & $44.6633 \pm 0.3838^{\mathrm{a}}$ & $56.2166 \pm 0.4344^{\mathrm{b}}$ & $56.2200 \pm 0.2197^{\mathrm{b}}$ \\
\hline SHRINKAGE & $20.9600 \pm 1.7807^{\mathrm{b}}$ & $10.6033 \pm 1.1270^{\mathrm{a}}$ & $14.5333 \pm 1.5592^{\mathrm{a}}$ \\
\hline MOISTURE RETENTION & $87.8000 \pm 0.2490^{\mathrm{a}}$ & $89.6533 \pm 0.3206^{\mathrm{b}}$ & $89.8866 \pm 0.2361^{\mathrm{b}}$ \\
\hline
\end{tabular}

\section{Proximate Composition}

The influences of various levels of potato on proximate characteristics of chicken cutlets are presented in Table 3. Increased levels of potato incorporation in the formulations reflected significantly $(\mathrm{P}<0.05)$ lower values of moisture content of cooked cutlets containing $50 \%$ potato than $25 \%$ and control however values did not differ significantly among $\mathrm{T}_{25}$ and CONTROL. CONTROL cutlets had highest protein values followed by $25 \%$ and $50 \%$ potato added cutlets. Reduction in protein content of cutlets containing potato as binder may be due to high starch and low protein content in potato. Fat content was significantly $(\mathrm{P}<0.05)$ higher for potato incorporated cutlets compared to CONTROL. This may be due to higher fat retention of product due to addition of boiled potato as binder. Total ash content did not significantly $(\mathrm{P}<0.05)$ affected by addition of various levels of potato in chicken cutlets.

Table 3: Effect of incorporation of boiled potato on proximate composition of chicken cutlets

\begin{tabular}{|c|c|c|c|}
\hline PARAMETERS & CONTROL & $\mathbf{T}_{25}$ & $\mathbf{T}_{\mathbf{5 0}}$ \\
\hline MOISTURE & $65.2833 \pm 0.5514^{\mathrm{a}}$ & $65.0933 \pm 0.4601^{\mathrm{a}}$ & $63.3100 \pm 0.2066^{\mathrm{b}}$ \\
\hline PROTEIN & $32.3100 \pm 0.6615^{\mathrm{b}}$ & $24.9466 \pm 1.0491^{\mathrm{b}}$ & $22.9033 \pm 1.6445^{\mathrm{a}}$ \\
\hline FAT & $6.1800 \pm 0.4899^{\mathrm{a}}$ & $6.7400 \pm 0.1221^{\mathrm{b}}$ & $7.4333 \pm 0.6333^{\mathrm{c}}$ \\
\hline ASH & $1.3666 \pm 0.1763^{\mathrm{a}}$ & $1.9333 \pm 0.2403^{\mathrm{a}}$ & $2.5333 \pm 0.5811^{\mathrm{a}}$ \\
\hline
\end{tabular}

\section{Sensory characteristics}

The results obtained in the sensory evaluation of chicken cutlets are presented in Table no.4. Colour and appearance scores gradually increased as the level of potato incorporation increased to $25 \%$. Colour and appearance scores were highly significant $(\mathrm{P}<0.01)$ for potato incorporated cutlets compared to CONTROL. No significant differences were observed with regard to flavour of cutlets incorporated with different levels of potato. No significant differences were observed in texture values in CONTROL and treatment values. Potato added cutlets had highly significant $(\mathrm{P}<0.01)$ values for juiciness due to high moisture absorbance capacity of boiled potato used as binder. However, the values of T25 and T50 did not differ significantly. All the potato incorporated cutlets had higher overall acceptability scores than the control cutlets because of the better colour and appearance and juiciness scores.

Table 4: Effect of incorporation of boiled potato on Sensory characteristics of chicken cutlets

\begin{tabular}{|c|c|c|c|}
\hline PARAMETERS & CONTROL & $\mathbf{T}_{25}$ & $\mathbf{T}_{\mathbf{5 0}}$ \\
\hline FLAVOUR & $6.8000 \pm 0.1154^{\mathrm{a}}$ & $7.2200 \pm 0.1331^{\mathrm{a}}$ & $7.0000 \pm 0.1154^{\mathrm{a}}$ \\
\hline COLOUR \& & $6.8666 \pm 0.0666^{\mathrm{a}}$ & $7.6000 \pm 0.0577^{\mathrm{b}}$ & $7.4000 \pm 0.0577^{\mathrm{c}}$ \\
APPEARANCE & & & \\
\hline TEXTURE & $6.6833 \pm 0.0928^{\mathrm{a}}$ & $6.8000 \pm 0.0577^{\mathrm{a}}$ & $6.3666 \pm 0.0882^{\mathrm{a}}$ \\
\hline JUICINESS & $7.0333 \pm 0.0881^{\mathrm{a}}$ & $7.3666 \pm 0.0333^{\mathrm{b}}$ & $7.4666 \pm 0.0333^{\mathrm{b}}$ \\
\hline OVERALL & $6.7333 \pm 0.1666^{\mathrm{a}}$ & $7.4666 \pm 0.0333^{\mathrm{b}}$ & $7.0666 \pm 0.0666^{\mathrm{a}}$ \\
ACCEPTABILITY & & & \\
\hline
\end{tabular}

From, the observations recorded in this study it can be concluded that incorporation of potato as binder and for value addition of chicken cutlets at $25 \%$ level improves the quality of chicken cutlets and also lowers the cost of production without any deleterious effect on the physico-chemical, nutritive and sensory qualities of the product. 


\section{References}

[1]. AOAC (1995). Official Method Of Analysis. $16^{\text {th }}$ edition. Association of Official Analytical Chemists, Washington, DC

[2]. Cunningham FE (1989). Developments in Enrobed products. In G.C. Mead (Ed.), Processing of Poultry (pp. 325-349)

[3]. El-MagoliS, Laroia S and Hansen P (1996). Flavour and texture characteristics of low fat ground beef patties formulated with whey protein concentrate. Meat Sci., 42(2): 179-193

[4]. Hedrick HB, Aberle ED, Forrest JC (1994) Principles of Meat Sci., pp. 144-150

[5]. Keeton JT 1983. Effect of fat and $\mathrm{NaCl} /$ phosphate levels on the chemical and sensory properties of pork patties. J. Of Food Sci., 48:878-881

[6]. Keeton JT 1994. Low-fat meats products technological problems with processing. Meat Sci.,36:261-276

[7]. Pathak V, Bhat ZF, Bukhari SAA and Ahmad SR (2009). Effects of different levels of porridge on the quality characteristics of chicken patties. Indian Journal of Poultry Sci., 44:87-90

[8]. Patil G and Sanyal MK (2001). Quality of chicken patties incorporated with milk-co-precipitates. Bev Food World. 28: 11-12

[9]. Rao VNM \& Delaney RAM (1995) An engineering perspective on deep fat frying of breaded chicken pieces. Food Technology, 49, $138-141$

[10]. Sharma BD, Kumar S and Nanda PK (1998). Development of low cost high value formulations for convenience meat products utilizing non-conventional extenders. Annual Report, Indian Vety. Research Institute, Izatnagar, Bareilly (U.P.). Sub Project-III, Division of L.P.T. pp 65-66

[11]. Singh RP and Verma (2000). Physico-chemical and Sensory quality of chicken patties as influenced by extender and packaging materials. Indian J. Poultry Sc. 35: 85-88

[12]. Snedecor GW \& Cochran WG (1989) Statistical methods , pp.72-148, $8^{\text {th }}$ edition

[13]. Trout ES, Hunt MC, Johnson DE, Claus JR, Kastner CL and Kropf DH (1992). Characteristics of low fat ground beef containing texture modifying ingredients. J. Of Food Sci., 57: 19-24

[14]. Yilmaz I and Daglioglu (2003). The effect of replacing fat with oat bran on fatty composition and physicochemical properties of meat balls. Meat Sci., 65: 819-823 